\title{
THE RISK ANALYSIS DURING PRODUCTION PROCESS OF AN INNOVATIVE BABY CARRIAGE WITH A BIKE FUNCTION
}

\section{ANALIZA RYZYKA PODCZAS PRODUKCJI INNOWACYJNEGO WÓZKA DZIECIĘCEGO Z FUNKCJĄ ROWERU}

\author{
Emil Nowiński, Damian Kopyt
}

Instytut Techniczny Wojsk Lotniczych e-mail: emil.nowinski@itwl.pl

\begin{abstract}
The article presents the risk assesment of damages occurance in production stage of a babycarriage with a bike function. The analysis of risk is done by using the FMEA - Failure Made and Effect Analysis that is used in aviation and automotive industry. This way of innovative product assessment allows to evaluate the risk of defects and indicate the priorities of quality for key parts as well as the device.
\end{abstract}

Keywords: FMEA analysis, innovative product, babycarriage with a bike function

Streszczenie: $W$ niniejszej publikacji przedstawiony zostat sposób oceny ryzyka wystapienia uszkodzeń na etapie produkcji produktu jakim jest wózek dziecięcy $z$ funkcja roweru. Analizy ryzyka dokonano metoda FMEA, powszechna $i$ uznawang $w$ przemyśle lotniczym $i$ motoryzacyjnym. Taki sposób oceny innowacyjnego produktu pozwala w sposób dość dokładny oszacować ryzyko, a także ustalić priorytety jakości zarówno dla kluczowych podzespolów, jak również dla catego urządzenia

Slowa kluczowe: analiza FMEA, innowacyjny produkt, wózek z funkcją roweru 
Analiza ryzyka podczas produkcji innowacyjnego wózka dziecięcego z funkcja... The risk analysis during production process of an innovative baby carriage...

\section{Wstęp}

Możliwość wystąpienia awarii maszyny czy urządzenia, w całym okresie jego eksploatacji jest istotnym czynnikiem wpływającym na komfort i ekonomikę użytkowania. Oprócz wymienionych aspektów, awaryjność maszyny wpływa także, a nawet przede wszystkim na bezpieczeństwo eksploatacji maszyny.

Jak wynika z przedstawionego poniżej rysunku 1, urządzenia techniczne cechują się najwyższym wskaźnikiem awaryjności w początkowej i końcowej fazie swojego „życia”.

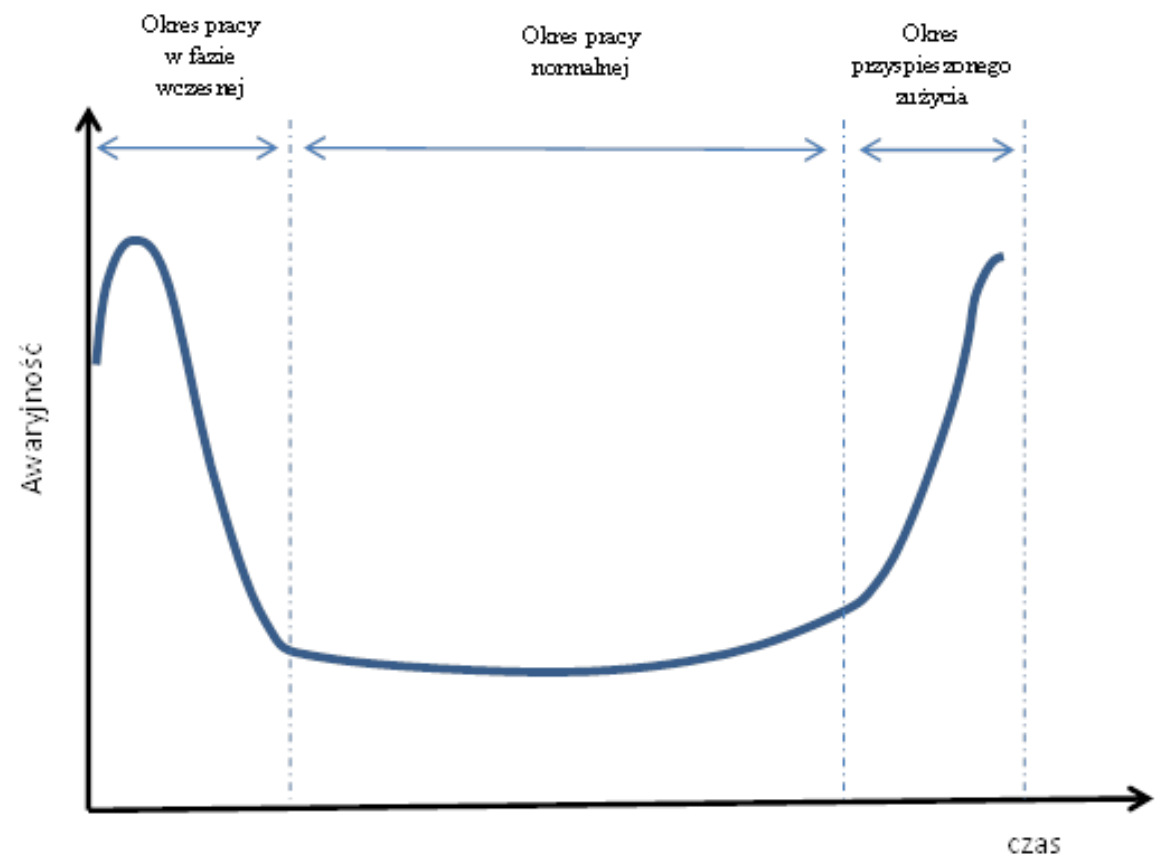

Rys. 1. Wykres awaryjności urządzeń technicznych w catym cyklu ich „życia”.

W początkowej fazie eksploatacji dochodzi do wielu awarii i usterek, które wynikają głównie z błędów projektowych, konstruktorskich oraz montażowych. W końcowym okresie eksploatacji wzmożona awaryjność również ma miejsce, co z kolei związane jest z dość istotnym zużyciem podzespołów współpracujących ze sobą, ale także ze zużyciem wynikającym ze „starzenia” (degradacji) materiałów konstrukcyjnych.

Prawidłowa eksploatacja zakłócana częstymi awariami wiąże się z niebezpieczeństwem i ryzykiem użytkowania maszyny. Istnieje wiele definicji ryzyka, jednak jedną z prostszych zaproponował Arrow [2] przedstawiając ryzyko jako ,jeden $\mathrm{z}$ wymiarów niepewności”. $Z$ kolei D. Błaszczuka definiuje ryzyko jako „możliwość wystąpienia skutków innych od oczekiwanych [2]. 
Skoro z definicji wynika, że ryzyko jest „wymiarem” należy sądzić, że da się go zmierzyć, a przynajmniej oszacować. Jedną z metod szacowania ryzyka jest metoda FMEA ( $\mathrm{z}$ ang. Failure Made and Effect Analysis). Jest ona uznawana jako jedna $z$ najlepszych technik analitycznych pozwalających na przejrzyste ustalenie związków między przyczynami i skutkami niedomagań (wad), szukanie rozwiązań oraz optymalizowanie podejmowania decyzji przy ich wyborze. Pozwala uzyskać pewność, że w projektowaniu wyrobów i ich produkcji, wszystkie możliwe ryzyka zostały wzięte pod uwagę.

\section{Analiza ryzyka według FMEA}

Metoda analizy ryzyka FMEA opisana jest w normie PN-IEC 812:1994 Procedura analizy rodzajów i skutków uszkodzeń. Metodologia ta oficjalnie została opracowana w USA i wydana 9 listopada 1949 roku jako procedura MIL-P 1629 „Procedure for Performing a Failure Mode, Effects and Criticality Analysis (FMECA)"'[3].

Na szeroką skalę FMEA zostało wykorzystane w NASA w latach sześćdziesiątych ubiegłego wieku do realizacji programu lotów kosmicznych „Apollo”. Metodą ta weryfikowano projekty różnych elementów statków kosmicznych, aby zapewnić bezpieczeństwo uczestnikom wyprawy. Po sukcesie w przemyśle kosmicznym, z FMEA korzystał także przemysł lotniczy i atomowy. Kilkanaście lat później metodę tą zaczęto wykorzystywać w przemyśle chemicznym, elektronicznym oraz samochodowym [1].

Metoda FMEA jest wykorzystywana przez organizacje do zapobiegania i ograniczania skutków wad, które występują w procesach konstrukcyjnych i wytwórczych. Jej zastosowanie polega na badaniu wszystkich możliwych usterek przed zatwierdzeniem rozwiązania konstrukcyjnego.

Podstawą funkcjonowania FMEA są założenia, że około $75 \%$ błędów wynika $\mathrm{z}$ nieprawidłowości $\mathrm{w}$ fazie przygotowania produkcji, a ich wykrywalność $\mathrm{w}$ fazie początkowej jest niewielka, natomiast około $80 \%$ błędów wykrywanych jest w fazie produkcji i jej kontroli, a także w czasie eksploatacji [4].

Cele FMEA to:

- konsekwentne i trwałe wyeliminowanie wad wyrobu (słabych miejsc wyrobu) przez rozpoznawanie rzeczywistych przyczyn ich powstania,

- unikanie wystąpienia rozpoznanych, a także jeszcze nieznanych wad w nowych wyrobach i procesach przez wykorzystanie wiedzy i doświadczeń z już przeprowadzonych analiz,

- ocena i zarządzanie ryzykiem [2].

Powody stosowania analizy FMEA to:

- spełnienie oczekiwań klienta,

- dostosowanie się do wymagań przepisów np. związanych z bezpieczeństwem produkcji, odpowiedzialnością za wyrób itp.,

- obniżenie kosztów jakości, 
Analiza ryzyka podczas produkcji innowacyjnego wózka dziecięcego z funkcja... The risk analysis during production process of an innovative baby carriage...

- podwyższenie jakości,

- skrócenie czasu związanego $\mathrm{z}$ wdrażaniem nowych technologii, wprowadzeniem nowych wyrobów na rynek itp.,

- coraz większa złożoność wyrobów, a wiąże się to $\mathrm{z}$ niebezpieczeństwem powstawania większej ilości wad podczas produkcji oraz większą ilością reklamacji,

- pomoc dotycząca podejmowania decyzji związanych z inwestycjami [4].

Analizie FMEA można poddać zarówno pojedynczy komponent oraz podzespół, jak i cały wyrób, fragment procesu oraz cały proces technologiczny. FMEA jest szczególnie polecana przy projektowaniu i produkcji nowego wyrobu, gdyż umożliwia rozpoznanie potencjalnych wad $\mathrm{z}$ takim wyprzedzeniem, aby można je było wyeliminować przed rozpoczęciem produkcji.

\section{Zalety FMEA:}

- wspomaga zarządzanie ryzykiem procesów,

- wskazuje słabe strony procesów zarządzania,

- faktycznie wpływa na poprawę poziomu jakości,

- jest narzędziem ciągłego doskonalenia,

- pozwala zapobiec wystąpieniu błędów wytwarzania/obsługi procesów/wyrobów,

- wymusza spojrzenia na problem z różnych perspektyw,

- poprawia możliwości realizacji oczekiwań klienta,

- obniża koszty uzyskiwania jakości,

- poprawia niezawodność produktów,

- wykorzystuje wiedzę pracowników, dzięki temu stosuje lepsze rozwiązania w produkcji wyrobów i świadczeniu usług,

- podnosi wiedzę fachową pracowników,

- umożliwia opracowanie banku danych dotyczącego powstałych błędów [2].

Analizę FMEA dokonać można zarówno jako analizę konstrukcji oraz procesów. FMEA konstrukcji przeprowadza się zawsze wtedy, gdy:

- istnieje potrzeba oceny nowego rozwiązania technicznego, które znaczenie odbiega od dotychczasowych rozwiązań, dla którego w przedsiębiorstwie brak jest wystarczającego doświadczenia;

- zastosowanie znajdują nowe materiały, w odniesieniu do których w wykonawstwie i/lub w użytkowaniu brak jest wystarczającego doświadczenia;

- dla realizacji wyrobu zastosowano nowoczesne procesy, dla których brak jest wystarczającego doświadczenia;

- dla wyrobu stawiane są specjalne wymagania bezpieczeństwa, które ograniczają możliwość roszczeń z tytułu odpowiedzialności za wadliwe działanie;

- dla realizacji wyrobu lub jego komponentów potrzebne są procesy o dużym znaczeniu dla ochrony środowiska lub bezpieczeństwa pracy; 
- w nowym wyrobie zostaną zastosowane części, nie mające dotychczas zastosowania;

- dla wykonania wyrobu potrzebne są procesy, nie mające dotychczas zastosowania;

- istniejący wyrób może być przeznaczony do innych, niż dotychczasowe, zastosowań [2].

Mając na uwadze powody dla których przeprowadzana jest analiza FMEA, ciekawym obiektem analizy ryzyka będzie konstrukcja innowacyjnego wózka dziecięcego $\mathrm{z}$ funkcją roweru.

\section{Obiekt badań}

Obiektem analizy FMEA jest prototyp wózka dziecięcego z funkcją roweru, przedstawiony na rys. 2 .

a)

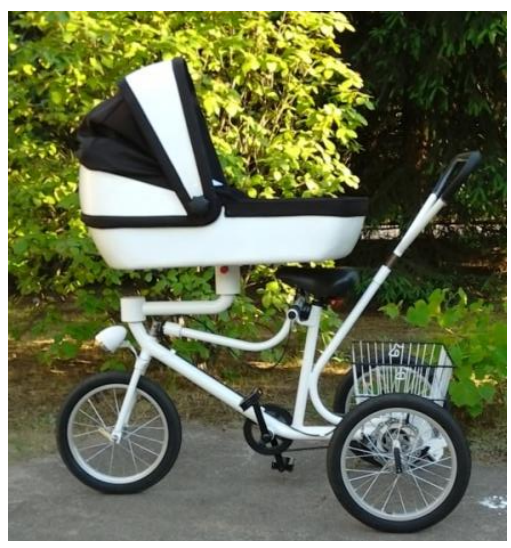

b)

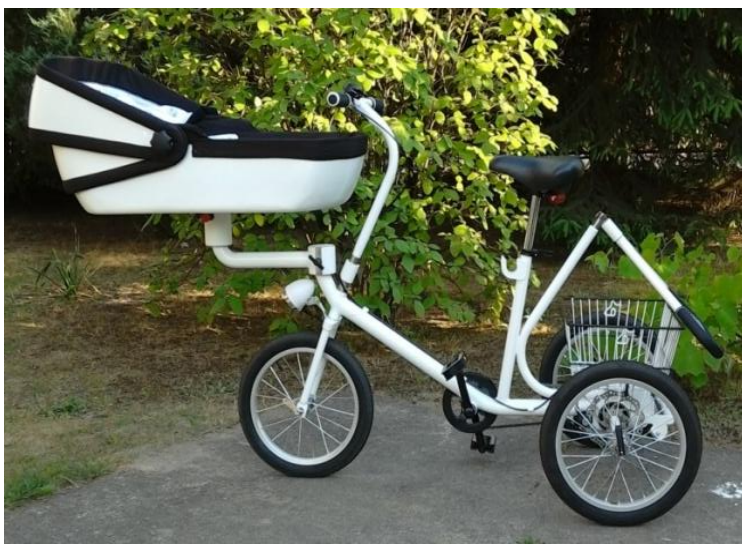

Rys. 2. Innowacyjny wózek; a) przystosowany do pchania, b) przystosowany do jazdy rowerowej.

Konstrukcja rowero - wózka może składać się z głębokiego wózka dziecięcego, wózka spacerowego, fotelika samochodowego oraz roweru trójkołowego. W ten sposób powstaje środek lokomocji do przewozu dzieci w różnych pozycjach. Wynalazek ten został zgłoszony do opatentowania (nr W.124162). Opisywany wózek z funkcją roweru posiada ramię obrotowe (obrót o $360^{\circ}$ ), na którym za pomocą systemu zatrzaskowego, jest montowana gondola. Ramię to wykorzystywane jest do ustalania dwóch stałych pozycji - pozycji „wózek” i pozycji „rower”. Służy do tego sworzeń zatrzaskowy, który umożliwia szybką transformację ustawień. Adapter, za pomocą którego montowana jest gondola z ramieniem obrotowym, posiada dodatkowo możliwość obrotu o $360^{\circ}$ z blokadą pozycji co $90^{\circ}$. 
Analiza ryzyka podczas produkcji innowacyjnego wózka dziecięcego z funkcja... The risk analysis during production process of an innovative baby carriage...

Kierownica roweru jest elementem ruchomym, który w zależności od ustawienia konstrukcji chowany jest pod gondolą, bądź służy do utrzymywania lub zmiany kierunku jazdy.

Kolejnym elementem umożliwiającym złożenie jest rączka wózka. Konstrukcja pozwala na demontaż i ponowny montaż wszystkich trzech kół. Dosyć szeroki rozstaw kół tylnych oraz obniżony środek ciężkości, z uwagi na zastosowanie kół o niewielkiej średnicy, uniemożliwiają przewrócenie się rowero - wózka podczas pokonywania zakrętów z prędkością, do jakiej obiekt ten został zaprojektowany.

Zaletami przedstawionej konstrukcji są:

- lepsza mobilność - opcja roweru umożliwia szybsze poruszanie się w porównaniu do tradycyjnego wózka dziecięcego,

- wielopunktowe pozycjonowanie ustawienia gondoli,

- wysokiej jakości hamulce tarczowe,

- odpowiednie pokrycie lakiernicze oraz materiał gondoli odbijające światło, ułatwiające widoczność i bezpieczeństwo jazdy w nocy,

- 5 - punktowe pasy bezpieczeństwa w gondoli,

- dodatkowe oświetlenie w postaci lamp LCD z przodu i z tylu roweru,

- umożliwienie montażu fotelika samochodowego za pomocą systemu zatrzaskowego,

- prostota przebudowy funkcjonalności konstrukcji oraz jej parkowanie,

- stabilność podczas jazdy.

\section{Analiza ryzyka na etapie produkcji wózka $\mathrm{z}$ funkcją roweru}

Z uwagi na większą liczbę zagrożeń wynikających z użytkowania, a także większe obciążenia i możliwość uszkodzenia konstrukcji, analizie FMEA poddany zostanie wózek rozłożony do funkcji roweru. $Z$ uwagi na złożoność problemów wynikających $\mathrm{z}$ eksploatacji urządzenia technicznego, w niniejszej publikacji rozpatrzona zostanie jedynie faza montażu wraz z kontrolą jakości urządzenia.

Analiza ryzyka wg metody FMEA polega na wskazaniu wszystkich możliwych wad i uszkodzeń całej konstrukcji, a także przeanalizowanie ich według kryteriów znaczenia wady, prawdopodobieństwa wykrycia wady oraz zdolności wykrycia wady. Każde z powyższych kryteriów oceniane jest w skali dziesięciostopniowej, przy czym ryzyko dla przyjętego kryterium jest tym większe im wyższa jest wartość liczbowa.

Ryzyko wystąpienia wybranej wady oceniane jest na podstawie otrzymanej liczby RPN (Risk Priority Number), która jest iloczynem wartości przyznanym kryteriom znaczenia wady, prawdopodobieństwa wykrycia wady oraz zdolności wykrycia wady. Liczbę RPN porównuje się z przyjętym dla wszystkich wad, granicznym ryzykiem $\mathrm{RPN}_{\mathrm{gr}}$, również wyrażanym w postaci liczby. Jeżeli wartość obliczonego ryzyka będzie większa od wartości założonego ryzyka, dla danego elementu, które powoduje zagrożenia, należy wprowadzić korekty na etapie projektu, konstrukcji, wykonania lub ograniczenia w użytkowaniu. 
Jak już wspomniano, liczbę RPN oblicza się na podstawie trzech zasadniczych kryteriów. Wzór do obliczeń matematycznych przedstawiono poniżej:

$$
\mathrm{RPN}=\mathrm{S} \times \mathrm{O} \times \mathrm{D}
$$

gdzie:

S (Severity) - znaczenie wady - jak istotne znaczenie dla klienta będzie miała dana wada.

$\mathrm{O}$ (Occurrence) - prawdopodobieństwo wystąpienia wady.

D (Detection) - wykrywalność wady - zdolność do wykrywania wady.

Wartości dla poszczególnych kryteriów, przyjmowane są $\mathrm{z}$ tabel 1,2,3 zamieszczonych poniżej.

Tabela 1. Kryteria liczbowego określenia znaczenia wady

\begin{tabular}{|c|c|c|}
\hline $\mathrm{S}$ & Znaczenie & FMEA procesu \\
\hline 1 & Żadne & $\begin{array}{l}\text { Wada nie będzie miała żadnego } \\
\text { przedsięwzięcia }\end{array}$ \\
\hline 2 & Bardzo małe & $\begin{array}{l}\text { Wada będzie miała minimalny, prawie nie zauważalny wpływ na } \\
\text { przebieg realizacji przedsiewziecia }\end{array}$ \\
\hline 3 & Małe & $\begin{array}{l}\text { Znaczenie wady jest małe i prowadzi tylko do niewielkiego } \\
\text { pogorszenia realizacji przedsiewziecia. }\end{array}$ \\
\hline 4 & \multirow{3}{*}{ Przeciętne } & $\begin{array}{l}\text { Wada jest zauważalna i powoduje niezadowolenie } \\
\text { uczestniczacych w realizacji przedsiewziecia }\end{array}$ \\
\hline 5 & & $\begin{array}{l}\text { Wada jest wyraźnie zauważalna, sposób realizacji projektu nie } \\
\text { zaspokaja potrzeb stron zainteresowanych, cel przedsięwzięcia jest } \\
\text { zagrożony }\end{array}$ \\
\hline 6 & & $\begin{array}{l}\text { Wada jest zauważalna, cel projektu nie może być osiągnięty, a } \\
\text { usuniecie wady generuje dodatkowe koszty. }\end{array}$ \\
\hline 7 & \multirow{2}{*}{ Duże } & $\begin{array}{l}\text { Niezadowolenie zainteresowanych stron jest znaczące, cel projektu } \\
\text { jest niemożliwy do zrealizowania. }\end{array}$ \\
\hline 8 & & $\begin{array}{l}\text { Niezadowolenie zainteresowanych stron jest tak duże, że } \\
\text { kontynuowanie projektu jest wyraźnie zagrożone }\end{array}$ \\
\hline 9 & \multirow[t]{2}{*}{ Krytyczne } & $\begin{array}{l}\text { Wada wyraźnie narusza spełnienie wymagań prawnych, stanowi } \\
\text { zagrożenie dla zainteresowanych stron a kontynuowanie projektu } \\
\text { może być niemożliwe. }\end{array}$ \\
\hline 10 & & $\begin{array}{l}\text { Wada jest tak duża, że nie można jej usunąć, poprawić. } \\
\text { Kontynuowanie projektu nie jest możliwe. }\end{array}$ \\
\hline
\end{tabular}

Tabela 2. Kryteria liczbowego określenia prawdopodobieństwa wystapienia wady

\begin{tabular}{|c|l|l|}
\hline O & Prawdopodobieństwo wystąpienia & Poziom prawdopodobieństwa \\
\hline 1 & Nieprawdopodobne & $\leq 1$ na 100000 \\
\hline 2 & Prawie nieprawdopodobne & 1 na 10000 \\
\hline 3 & Rzadko & 1 na 2000 \\
\hline 4 & \multirow{3}{*}{ Przeciętnie } & 1 na 1000 \\
5 & & 1 na 500 \\
6 & & 1 na 200 \\
\hline 7 & \multirow{2}{*}{ Często } & 1 na 100 \\
8 & \multirow{2}{*}{ Bardzo często } & 1 na 50 \\
\hline 9 & & 1 na 20 \\
\cline { 1 - 1 } 10 & & $\geq 1$ na 10 \\
\hline
\end{tabular}


Analiza ryzyka podczas produkcji innowacyjnego wózka dziecięcego z funkcja... The risk analysis during production process of an innovative baby carriage...

Tabela 3. Kryteria liczbowego określenia wykrywalności wady

\begin{tabular}{|c|l|l|}
\hline D & $\begin{array}{l}\text { Wykrywalność } \\
\text { wady }\end{array}$ & \multicolumn{1}{|c|}{ FMEA procesu } \\
\hline 1 & Pewna & $\begin{array}{l}\text { Projekt jest zabezpieczony przed powstawaniem wady. Nie ma } \\
\text { możliwości popehnienia blędu. Wada jest zawsze wykryta. }\end{array}$ \\
\hline 2 & Bardzo wysoka & $\begin{array}{l}\text { Projekt nie zostanie przekazany do dalszej realizacji z wadą. } \\
\text { Kontrola jest automatyczna, stwierdzenie wady wstrzymuje proces. } \\
\text { Wada jest prawie zawsze wykryta. }\end{array}$ \\
\hline 3 & Wysoka & $\begin{array}{l}\text { Kontrola jest przeprowadzana na bieżąco. Jest duże } \\
\text { prawdopodobienstwo, że wada zostanie w porę wykryta. }\end{array}$ \\
\hline 4 & $\begin{array}{l}\text { Umiarkowanie } \\
\text { wysoka }\end{array}$ & $\begin{array}{l}\text { Kontrola w postaci wielu sprawdzeń na dalszych etapach projektu. } \\
\text { Jest duże prawdopodobieństwo, że wada zostanie w porę wykryta. }\end{array}$ \\
\hline 5 & Przeciętna & $\begin{array}{l}\text { Kontrola jest oparta na pomiarach przeprowadzanych po } \\
\text { zakończeniu danego etapu projektu np. weryfikacja zgodności. } \\
\text { Kontrola może wykryć wadę. }\end{array}$ \\
\hline 7 & Niska & $\begin{array}{l}\text { Etap jest nadzorowany tylko przez bieżace monitorowanie } \\
\text { poprawności lub metody szacunkowo-statystyczne. Kontrola może } \\
\text { nie wykryć wady. }\end{array}$ \\
\hline 8 & Niepewna & $\begin{array}{l}\text { Kontrola polega tylko na dwustopniowej ocenie intuicyjnej } \\
\text { i ma małe szanse na wykrycie wady. }\end{array}$ \\
\hline 9 & $\begin{array}{l}\text { Kontrola polega tylko na pojedynczej ocenie intuicyjnej } \\
\text { i ma male szanse na wykrycie wady. }\end{array}$ \\
\hline 10 & niepewna & $\begin{array}{l}\text { Kontrola jest wykonywana sporadycznie i nie jest ukierunkowana } \\
\text { na analizę wad. Kontrola prawdopodobnie nie wykryje wady }\end{array}$ \\
\hline
\end{tabular}

Definiowanie wad obiektu badań dotyczyć będzie niezawodności wyrobu przedstawionego na rys. 3 na etapie produkcji.

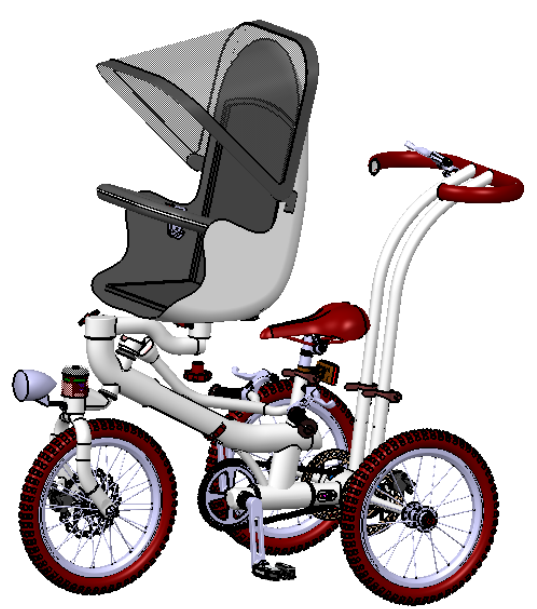

Rys. 3. Projekt wózka z funkcją roweru, dla którego przeprowadzona została analiza FMEA. 
Poniżej w tabeli 4 dokonano oceny ryzyka wystąpienia wad na etapie produkcji rowero - wózka.

Tabela 4. Analiza FMEA wystapienia wad $w$ innowacyjnym wózku z funkcja roweru.

\begin{tabular}{|c|c|c|c|c|c|c|}
\hline $\begin{array}{l}\text { Potencjalny } \\
\text { rodzaj wady }\end{array}$ & Możliwa przyczyna wady & 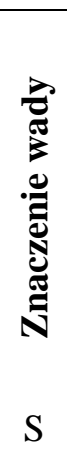 & 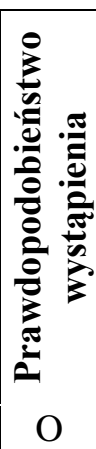 & 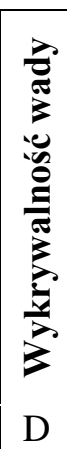 & Z & 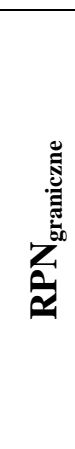 \\
\hline $\begin{array}{l}\text { Uszkodzenie } \\
\text { obręczy koła }\end{array}$ & $\begin{array}{l}\text { Wykrzywiona obręcz, zdecentro- } \\
\text { wana piasta koła, wyszczerbienia } \\
\text { obręczy }\end{array}$ & 6 & 3 & 2 & 30 & 210 \\
\hline $\begin{array}{ll}\text { Pęknięta } & \text { tarcza } \\
\text { hamulcowa } & \end{array}$ & $\begin{array}{l}\text { Uszkodzenie mechaniczne, niewła- } \\
\text { ściwa obróbka cieplna, naprężenia } \\
\text { mechaniczne }\end{array}$ & 8 & 2 & 2 & 36 & 210 \\
\hline $\begin{array}{l}\text { Uszkodzone szczęki } \\
\text { i klocki hamulcowe }\end{array}$ & $\begin{array}{l}\text { Pęknięte klocki, zdeformowane } \\
\text { klocki hamulcowe, blokujące się } \\
\text { szczęki hamulcowe }\end{array}$ & 7 & 5 & 4 & 140 & 210 \\
\hline $\begin{array}{l}\text { Zdeformowana } \\
\text { opona }\end{array}$ & $\begin{array}{l}\text { Wada produkcyjna, źle dobrany } \\
\text { skład chemiczny }\end{array}$ & 4 & 5 & 7 & 140 & 210 \\
\hline $\begin{array}{l}\text { Luzy na połącze- } \\
\text { niach piasty koła } z \\
\text { widelcem }\end{array}$ & $\begin{array}{l}\text { Nieprawidłowy montaż, źle } \\
\text { dobrane podzespoły, niedokładna } \\
\text { obróbka mechaniczna }\end{array}$ & 8 & 4 & 2 & 64 & 210 \\
\hline $\begin{array}{l}\text { Uszkodzenie me- } \\
\text { chaniczne rucho- } \\
\text { mych elementów } \\
\text { konstrukcyjnych } \\
\text { roweru }\end{array}$ & $\begin{array}{l}\text { Nieprawidłowy montaż, źle } \\
\text { dobrane podzespoły, niedokładna } \\
\text { obróbka mechaniczna }\end{array}$ & 9 & 5 & 3 & 135 & 210 \\
\hline $\begin{array}{l}\text { Uszkodzenie me- } \\
\text { chaniczne rucho- } \\
\text { mych elementów } \\
\text { konstrukcyjnych } \\
\text { uchwytu wózka }\end{array}$ & $\begin{array}{l}\text { Nieprawidłowy montaż, źle } \\
\text { dobrane podzespoły, niedokładna } \\
\text { obróbka mechaniczna }\end{array}$ & 9 & 6 & 2 & 108 & 210 \\
\hline $\begin{array}{l}\text { Uszkodzenie ramy } \\
\text { roweru }\end{array}$ & $\begin{array}{l}\text { Deformacja ramy, błędy } \\
\text { technologiczne, nniedokładność } \\
\text { połączeń nierozłącznych }\end{array}$ & 9 & 4 & 3 & 108 & 210 \\
\hline
\end{tabular}


Analiza ryzyka podczas produkcji innowacyjnego wózka dziecięcego z funkcja... The risk analysis during production process of an innovative baby carriage...

Tabela 4. Analiza FMEA wystapienia wad $w$ innowacyjnym wózku z funkcja roweru (c.d.).

\begin{tabular}{|c|c|c|c|c|c|c|}
\hline $\begin{array}{l}\text { Potencjalny } \\
\text { rodzaj wady }\end{array}$ & Możliwa przyczyna wady & 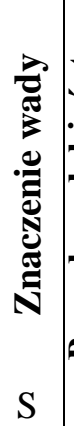 & 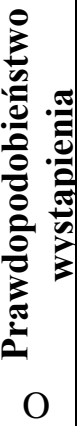 & 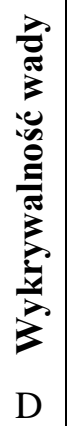 & Z & 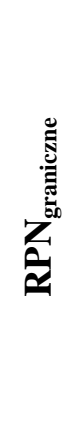 \\
\hline $\begin{array}{l}\text { Uszkodzenie } \\
\text { mechanizmu } \\
\text { napędzającego } \\
\text { koła }\end{array}$ & $\begin{array}{l}\text { Wyszczerbienie zęba zębatki, } \\
\text { nadmierne opory ruchu mecha- } \\
\text { nizmu napędowego, głośna } \\
\text { praca mechanizmu napędowego, } \\
\text { nadmierne luzy wrzeciona } \\
\text { napędowego }\end{array}$ & 8 & 4 & 5 & 160 & 210 \\
\hline $\begin{array}{l}\text { Uszkodzenie } \\
\text { łańcucha } \\
\text { napędowego }\end{array}$ & $\begin{array}{l}\text { Pęknięcie ogniw lączących, } \\
\text { nadmierne luzy, niedostateczne } \\
\text { luzy }\end{array}$ & 7 & 5 & 5 & 175 & 210 \\
\hline $\begin{array}{l}\text { Uszkodzenie } \\
\text { mechanizmu } \\
\text { przerzutek }\end{array}$ & $\begin{array}{l}\text { Błędy montażowe, błędy } \\
\text { technologiczne, nieprawidłowa } \\
\text { regulacja }\end{array}$ & 6 & 4 & 4 & 96 & 210 \\
\hline $\begin{array}{l}\text { Uszkodzenie } \\
\text { siodełka }\end{array}$ & $\begin{array}{l}\text { Pęknięcie sprężyn amortyzują- } \\
\text { cych, błędy technologiczne, } \\
\text { błędy montażowe, brak możli- } \\
\text { wości stabilizacji siodełka }\end{array}$ & 8 & 4 & 3 & 96 & 210 \\
\hline $\begin{array}{l}\text { Uszkodzenie } \\
\text { ramienia } \\
\text { mocującego } \\
\text { gondolę/ fotelik }\end{array}$ & $\begin{array}{l}\text { Błędy technologiczne, błędy } \\
\text { montażowe, zbyt duże opory } \\
\text { ruchu ramienia, nadmierne luzy } \\
\text { w piaście ramienia }\end{array}$ & 9 & 4 & 3 & 108 & 210 \\
\hline $\begin{array}{l}\text { Uszkodzony } \\
\text { mechanizm } \\
\text { kierowania } \\
\text { rowerem }\end{array}$ & $\begin{array}{l}\text { Błędy montażowe, błędy techno- } \\
\text { logiczne, zastosowanie niewłaści- } \\
\text { wych części zamiennych }\end{array}$ & 9 & 3 & 3 & 81 & 210 \\
\hline $\begin{array}{l}\text { Uszkodzone } \\
\text { ramię do pchania } \\
\text { wózka }\end{array}$ & $\begin{array}{l}\text { Nadmierny luz montażowy, brak } \\
\text { możliwości złożenia ramienia, } \\
\text { brak możliwości zablokowania } \\
\text { ramienia, pęknięcia w miejscu } \\
\text { mocowania }\end{array}$ & 8 & 5 & 3 & 120 & 210 \\
\hline $\begin{array}{l}\text { Uszkodzone } \\
\text { światło } \\
\text { zewnętrzne }\end{array}$ & $\begin{array}{llr}\text { Pęknięta } & \text { lampa, } & \text { błędy } \\
\text { montażowe, spalona żarówka } \\
\text { lub dioda LED, uszkodzony } \\
\text { podzespół zasilający }\end{array}$ & 6 & 6 & 4 & 144 & 210 \\
\hline
\end{tabular}


Jak wynika z powyższej tabeli, poszczególne wartości ryzyka oszacowane dla konkretnych wad, które mogą wystąpić w procesie produkcji wózka z funkcją roweru, mieszczą się $w$ granicach $30-175$. Otrzymane wartości są mniejsze aniżeli założona wartość graniczna RPN wynosząca 210. Wartość graniczna RPN ustalona została dla $\mathrm{S}=7, \mathrm{O}=6$ i $\mathrm{D}=5$. Są to wartości wskaźników ryzyka, które pokazują, że jakakolwiek wada zaistniała w procesie produkcji jest niepożądana i będzie eliminowana, na etapie montażu oraz kontroli jakości gotowego wyrobu.

$\mathrm{Z}$ uwagi na różnorodność podzespołów, elementów, a także procesów technologicznych zastosowanych do ich produkcji, niezwykle trudno jest oszacować prawdopodobieństwo wystąpienia usterki podczas montażu i wstępnej kontroli jakości. Dlatego też prawdopodobieństwo wystąpienia usterki przyjęte zostało jako przeciętne. Nawet w przypadku nieznacznego zwiększenia częstotliwości występowania usterek, uzyskane wyniki RPM nie powinny przekroczyć założonej granicznej wartości ryzyka. Jeśli jednak z przyczyn niezależnych od producenta wózków, dostarczona zostanie wadliwa partia podzespołów, zakłada się, że zostanie ona właściwie rozpoznana i wycofana $\mathrm{z}$ linii montażowej, a także wymieniona na pozbawioną wad.

Oszacowane ryzyka cząstkowe, których wartości są wyższe niż 100, wynikają głównie z wagi jaką przykłada się do niezawodności danego elementu. Te właśnie podzespoły powinny być objęte szczególnym nadzorem nad jakością wykonania, montażu oraz funkcjonalnością.

\section{Podsumowanie}

Przedstawiona $\mathrm{w}$ artykule metoda oceny ryzyka procesu produkcji wózka z funkcją roweru ma duże znaczenie dla jakości produkowanych, a następnie eksploatowanych innowacyjnych produktów. Dzięki niej istnieje możliwość ustalania priorytetów jakości dla wyrobu w fazie projektowania, konstruowania, montażu oraz eksploatacji gotowego wyrobu.

Wykonana analiza ryzyka pokazuje, że założony przez producenta rowero-wózka sposób weryfikacji możliwych uszkodzeń w fazie montażu i kontroli jakości jest właściwy i prowadzi do otrzymywania produktu o wysokiej jakości wykonania, co powinno przełożyć się na jego trwałość i niezawodność.

\section{Literatura}

[1] Rychły - Lipińska A.:FMEA - analiza rodzajów błędów i ich skutków. Zeszyty Naukowe Instytutu Ekonomii i Zarządzania Politechniki Koszalińskiej 11/2007, Koszalin 2007.

[2] Kulińska E.: Metody analizy ryzyka w procesach logistycznych. Logistyka 2/2011. Wydawnictwo Instytutu Logistyki i magazynowania, Poznań 2011. 
Analiza ryzyka podczas produkcji innowacyjnego wózka dziecięcego z funkcja...

The risk analysis during production process of an innovative baby carriage...

[3] Świderski A., Ocena skuteczności procesu projektowania technicznych środków transportu $\mathrm{z}$ wykorzystaniem metody FMEA, Prace Naukowe Politechniki Warszawskiej, zeszyt 64 Transport. Warszawa 2008

[4] Kulińska E., Dornfeld A.: Zarządzanie ryzykiem procesów. Identyfikacja Modelowanie - Zastosowanie., Wydawnictwo Politechniki Opolskiej, Opole 2009.

[5] MIL-STD 1629A:1980: Procedure for Performing a Failure Mode, Effects and Criticality Analysis.

[6] Szkoda J., Świderski A.: Problemy oceny skuteczności jakościowej procesów realizacji wyrobów w aspekcie wymagań AQAP, EIJ, Warszawa 2005.

[7] Szkoda J., Kubicki A.: Wyznaczanie ryzyka wadliwości techniki wojskowej za pomocą metody FMEA, Mat. konferencyjne nt. Problemy eksploatacji techniki wojskowej. Kielce 2000.

[8] Zdanowicz R., Kost G.: Wykorzystanie metody FMEA do poprawy jakości i produktów. Problemy jakości 07/2001.

[9] Dokumentacja techniczno - użytkowa wózka dziecięcego z funkcją roweru KoppyBaby.

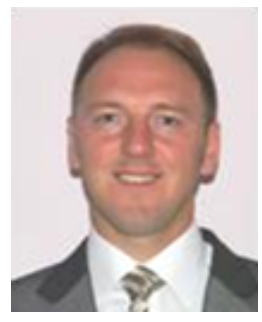

dr inż. Emil Nowiński - starszy specjalista badawczo techniczny w Instytucie Technicznym Wojsk Lotniczych. 